Jorida Xhafaj, Dr. Sc.

University for Business and Technology, Kosovo

\title{
THE RIGHT TO BE FORGOTTEN: A CONTROVERSIAL TOPIC UNDER THE GENERAL DATA PROTECTION REGULATION
}

\section{TIESĪBAS TIKT AIZMIRSTAM: VISPĀRĪGO DATU AIZSARDZĪBAS REGULAS KONTEKSTĀ PRETRUNĪGI VËRTẼTA TẼMA}

\begin{abstract}
Kopsavilkums
Jaunais datu aizsardzības regulējums attiecībā uz tiesībām tikt aizmirstam piedāvā indivīdiem iespēju bez liekas kavēšanās no datu pārziņa panākt no šiem indivīdiem iegūto personas datu dzēšanu. Šìs tiesības izraisījušas debates, kas saistītas ar datu pārziņa veiktas datu apstrādes pārliecinošiem likumīgiem pamatiem, kas būtu primāri pār datu subjekta interesēm, tiesībām un brīvībām, vai pār tiesisku prasījumu pamatošanu, ìstenošanu vai aizstāvēšanu. Tātad tiesības tikt aizmirstam tiek piemērotas ar īpašiem izṇēmumiem, jo seviš̌ki gadỉjumos, kad personas dati saskaņā ar VDAR tiek apstrādāti nelikumīgi.

Šì darba mērḳis ir analizēt iemeslus, kuru dēḷ datu dzēšanas tiesības var tikt atsauktas atbilstoši VDAR 17. panta 3. punktā noteiktajiem ierobežojumiem - priekšnosacijumu kopumam, kas jāizpilda, lai panāktu pagātnē iegūtās informācijas dzēšanu. Tiks analizēta arī Eiropas Kopienu Tiesas (EKT) un Eiropas Cilvēktiesību tiesas (ECT) lēmumu būtība, kuru rezultātā izstrādāts kritēriju kopums, lai atrastu saprātīgus risinājumus, panākot līdzsvaru starp šīm tiesībām un vārda un informācijas brīvību, mūsu tiesībām atcerēties un tiesiskās paļāvības nodrošināšanu.

Pētijums apliecina nepieciešamību līdzsvarot paaugstinātu kontroli pār indivīdiem un citas pamattiesības saskaņā ar proporcionalitātes principu.
\end{abstract}

Atslēgvārdi: VDAR, tiesības tikt aizmirstam, pārbaude, ierobežojumi, ECT, EKT

\section{Summary}

The new regulation of data privacy on the right to be forgotten offers the possibility of the individuals to obtain from the data controller the erasure of personal data concerning him or her without undue delay. This right has conceived a debate related to compelling legitimate grounds, of the controller, for the processing which override the interests, rights and freedoms of the data subject or for the establishment, exercise or defense of legal claims. Consequently, the exercise of the right to be forgotten is applied under specific exemptions and especially when personal data is processed unlawfully under the GDPR. The purpose of this paper is to analyse the grounds whereby the right of erasure can be invoked from the perspective of restrictions, established by applying paragraph 3 of Article 17 of the GDPR, as a set of conditions, which has to be fulfilled commutatively, to gain the erasure of past information. The article will also provide the analysis of the essence of the decisions of European Court of Justice (ECJ) and the European Court of Human Rights (ECtHR), which has developed a set of criteria to find the reasonable solutions in 
realizing the balance between this right and the freedom of expression and information, our right to remember and the necessity of legal certainty.

The research result of the paper consists on the necessity to balance the increased control of individuals against other fundamental rights, in accordance with the principle of proportionality.

Keywords: GDPR, the right to be forgotten, examination, limitations, ECtHR, ECJ

\section{Introduction}

Privacy and the right to be forgotten represent a fundamental human right, which has been defined as a notion abreast with the dynamic of the technology development and the digital longevity. This concept has been refined in parallel with debates on information access and control that are oriented from the rise of the right to know, public interest and security. The General Data Protection Regulation, which has become applicable on 25 May 2018, provides a clearer formulation of the right to erasure, ensuring undeviating implementing regime as one of the most controversial issues of the GDPR rules, posing it before insecurity in achieving the aims of being forgotten because of different legal and practical resolutions.

This paper examines the core conditions and obligations related to right of erasure, the disputable aspects in rewiring a delisting request and the conflict with other codified rights. The second section of the paper outlines the principles and criteria used to find the reasonable and fair balance in case of limitation of right, seen from the viewpoint of public interest, the freedom of expression, the public impact of data subject or to the method of obtaining the information, developed in important and recent ECJ or ECtHR's decisions.

The paper concludes with reflection on the importance of the principle of proportionality, in evaluation of specific circumstances and conditions of the case in reciprocal infringements between right to be forgotten and the freedom of expression and other protected rights. The recommendations are focused on transparency and necessity of clear legal principles, dedicated in deciding the relevance of a request and how controllers decide to delist or retain the requested personal information.

\section{The recognition of the right to be forgotten}

The right to control the information about themselves symbolizes the right to be left alone, which includes the right to control the dissemination of information about them. Also, this concept has been refined parallel with debates on information access and control that are oriented from the rise of the right to know, public interest and the data protection right.

Beginning with the first information privacy statute in Wiesbaden, Germany in the 1970s, from the perspective of a special framework, and later in EU nations data 
protection statutes, as well in Sweden, Austria, Denmark, France, and Norway ${ }^{1}$, the individual has been granted the right to demand removal of data about themselves in search engine results referred to as the "right to be forgotten" or "right of oblivion"2. According to the doctrine on conceptions of the informational self-determination ${ }^{3}$, the right to oblivion, which historically has been applied earlier "in exceptional cases involving an individual who has served a criminal sentence and wishes to no longer be associated with the criminal actions. Oblivion finds its rationale in privacy as a fundamental right related to human dignity, personality, reputation, and identity"4. Analysing this concept without considering other fundamental rights and principles of the democratic societies, we can agree that under the right of oblivion the subject of information is guaranteed that his/her data will be erased in case of lack of necessity or according to the circumstances where there exists excessive information.

At the core of the European data protection framework is the Data Protection Directive ${ }^{5}$, where the right to be forgotten has been defined in terms that all the European states have had the responsibility of implementation. Based on the Article 12, it was required from the Member States to enable the data subject to obtain from the controller, depending on the circumstances, "the rectification, erasure or blocking of his data, the processing of which does not comply with the provisions of the Directive, in particular because of the incomplete or inaccurate nature of the data"6. Consequently, in compliance with the mentioned decision it empowers the data subject to be vigilant that the personal data concerning him are correct and that they are processed in a lawful manner?

Schwartz P. The EU-U.S. Privacy Collision: A Turn to Institutions and Procedures. Available at: https://scholarship.law.berkeley.edu/cgi/viewcontent.cgi?article=2906\&context=facpubs [last viewed March 10, 2019].

2 The term originates from French, "Le droit á l'oubli". See Bernal P. A. A Right to Delete? European Journal of Law and Technology, 2011, Vol. 2, No. 2.

3 This concept is used based on the German constitutional ruling relating to personal information, defined as "the authority of the individual to decide by him, on the basis of the idea of selfdetermination, when and within what limits information about his private life should be communicated to others". See Rouvroy A., Poullet Y. The Right to Informational Self-Determination and the Value of Self-Development: Reassessing the Importance of Privacy for Democracy. Available at: https://www.researchgate.net/publication/225248944_The_Right_to_Informational_Self-Determination_and_the_Value_of_Self-Development_Reassessing_the_Importance_of_Privacy_for_ Democracy [last viewed May 2 , 2019].

4 Ambrose M. L, Ausloos J. The Right To Be Forgotten Across The Pond. Available at: https://www. jstor.org/stable/pdf/10.5325/jinfopoli.3.2013.0001.pdf?refreqid=excelsior\%3Ae22d710ee435df378449357e74c68a0f [last viewed May 6, 2019].

5 Directive 95/46/EC of the European Parliament and of the Council of 24 October 1995 on the protection of individuals with regard to the processing of personal data and on the free movement of such data. Available at https://eur-lex.europa.eu/legal-content/en/TXT/?uri=CELEX\%3A31995L0046 [last viewed May 31, 2019]. The right to erasure is mentioned in Article 12, guaranteeing of every data subject the right to obtain from the controller the rectification, erasure or blocking of data the processing of which does not comply with the provisions of the Directive, in particular because of the incomplete or inaccurate nature of the data.

6 Judgment of Court of Justice of the European Union in joined cases No. C-141/12 and C-372/12 YS v. Minister voor Immigratie, Integratie en Asiel and Minister voor Immigratie, Integratie en Asiel v. M and S.

7 Judgment of Court of Justice of the European Union in joined cases No. C-141/12 and C-372/12 YS v. Minister voor Immigratie, Integratie en Asiel and Minister voor Immigratie, Integratie en Asiel v. M and S. 
The right to be forgotten guaranteed by Article 17 of the GDPR permits the data subject "to obtain from the controller the erasure of personal data concerning him or her without undue delay", and defines core obligations of the controller "to inform third parties which are processing such data that an erasure request has been made, and if the controller has authorized a third party to publish such personal data, the controller remains responsible". So, as can be noted the right of erasure foreseen in the EU directive enrooted the recognition of the right to be forgotten by explaining in general terms or with potential equivoques regarding the discussions on reciprocal infringements of fundamental rights. According to the applicable provision, the erasure will be accomplished, if a set of two conditions exists, starting with the verification of any of the determined grounds ${ }^{8}$. So, on the one hand, the data subject gains more power over personal data through delisting request, when there is no legitimate reason to keep them. On the other hand, the restrictions established by applying paragraph 3 of Article $17^{9}$ of the GDPR requires confirmation of the lack of implications from other protected individual rights or public interest. Both conditions mentioned above have to be fulfilled commutatively and simultaneously. We consider that each of the limitations opposing the data subjects' requests are categories of rights with a broad scope, and therefore require thorough scrutiny, but despite this, generally space still remains for further discussions, which is the reason why many of such cases are being referred to $\mathrm{ECHR}^{10}$.

In view of the immense memory of the Internet and of the processed information, the impression of obstacles of breaking with the past or dangers faced by online living have been perceived. The approach on the extension of the impact of the past information elimination is necessary to be analyzed with focus on the indicators needed to resolve the dilemma.

\section{Exceptions and limitations}

The right to be forgotten has raised issues with different legal and practical resolutions, which make this concept a controversial one and also pose it before insecurity in achieving the aims of being forgotten. Among the disputable questions, which are

8 Based on Article 17 of GDPR, data subject can exercise the right to be forgotten when it is applied on the grounds related to necessity based on the purpose; withdrawal of the consent on which the processing is based; lack of overriding legitimate grounds for the processing; unlawfulness of processing; compliance with a legal obligation in Union or Member State law to which the controller is subject; necessity to offer information society services referred directly to a child.

9 According to this paragraph, the right of erasure shall not apply to the extent that processing is necessary for exercising the right of freedom of expression and information; for compliance with a legal obligation which requires processing by Union or Member State law to which the controller is subject or for the performance of a task carried out in the public interest or in the exercise of official authority vested in the controller; for reasons of public interest in the area of public health; for archiving purposes in the public interest, scientific or historical research purposes or statistical purposes; or for the establishment, exercise or defense of legal claims.

10 Wechsler S. The Right to Remember: The European Convention on Human Rights and the Right to Be Forgotten. Available at: http://jlsp.law.columbia.edu/wp-content/uploads/sites/8/2017/03/49Wechsler.pdf [last viewed May 5, 2019]. 
related to the territorial jurisdictions, extent of the information erasure and the proportionality with other codified rights, we have chosen to analyse only the last one, due to the limited scope of the current paper.

Undoubtedly, this kind of control over personal data is applied on the basis of an elaborated opinion, ensuring that this right is not unconditional ${ }^{11}$. The removal of past information from search engines presumes a latent conflict between what it is gained and what will be lost. The prevalence of this legal possibility needs to be resolved through clear principles and the balance with other interests ${ }^{12}$. Referring to the controversial decision ${ }^{13}$, which instigated a dispute on how information erasure can affect other protected rights by laws, European Court of Justice has created a basis of arguments from the official interpretation of the legal framework. It has stressed the safeguard of the right to be forgotten in case of "inadequate, irrelevant or no longer relevant, or excessive information in relation to the purposes of the processing at issue carried out by the operator of the search engine". Also, the ECJ addresses from its perspective that as the main criteria in this explication is the "fair balance" 14 between legitimate public interests of searchers and the data protection rights of the data subject. We found this in compliance with Convention for the Protection of Human Rights and Fundamental Freedoms and several decisions of the European Court of Human Rights, which consider the freedom of expression and privacy, by the context of press publications "as a matter of principle these rights deserve equal respect or equal weight ${ }^{15}$ ". The European Court of Human Rights has developed a set of criteria to find the reasonable and fair solutions, summarizing them as contribution to a debate of general interest ${ }^{16}$, interference with the right to data protection with respect to access documents needs a specific and legitimate interest ${ }^{17}$, the method of obtaining the

11 Reding V. Your data, your rights: Safeguarding your privacy in a connected world. Available at: file:/// Users/mac/Downloads/SPEECH-11-183_EN\%20(1).pdf [last viewed May 31, 2019].

12 Advocate General's Opinion in case No. C-390/18 proposes that the Court should balanced the right to be forgotten against other fundamental rights, such as the right to data protection, privacy and the legitimate public interest in accessing information. Available at: https://curia.europa.eu/jcms/upload/ docs/application/pdf/2019-01/cp190001en.pdf. [last viewed May 20, 2019].

13 Judgment of European Court of Human Rights, case No. C-131/12, Google Spain SL, Google Inc. v. Agencia Espanola de Proteccion de Datos, Mario Costeja Gonzalez, p. 81.

14 Ibid.

15 Judgment of European Court of Human Rights, case No. 40660/08 and 60641/08 Von Hannover v. Germany; See also Judgment of European Court of Human Rights, case No.: 33846/07 Węgrzynowski and Smolczewski v. Poland, p. 5.

16 ECtHR took account the contribution to any debate of general interest to society in case of information disclosure, Judgment of European Court of Human Rights, case No. 23373/03 Biriuk v. Lithuania; See also Judgment of European Court of Human Rights case No. 36919/02 Armonas v. Lithuania.

17 Judgment of European Court of Human Rights, case No. [2018] EWHC 799 (QB) NT1 and NT2 v. Google LLC. The court has reached different decisions about delisting requests of the subjects based on the evaluation of "sufficient legitimate interest to users of Google to justify its continued availability". Moreover, the court has stressed, "the specific rights asserted by the individual concerned will still need to evaluate the justified inference of the privacy based on relevant factors of the case". 
information ${ }^{18}$ and its accuracy ${ }^{19}$, the content and consequences of the publication ${ }^{20}$, the publicity of the person concerned and the impact of the limitations, which have to be proportionate with the intended aim ${ }^{21}$.

Some of these criteria match to the limitation in the paragraph 3 of Article 17 of GDPR, with regard to the right to be forgotten and other data subject rights such as public interest and security, the right of freedom of expression and information, the compliance of legal obligation, purposes of archiving in a public, statistical or scientific interest, the context of past prosecutions and penalties. It can be observed a direct correlation between them, and more concretely about the limitations related to the general or public interest, the freedom of expression, to the profile of the subject of the data or to the method of obtaining the information. Moreover, their relevance confirmation in confrontation with the right of data protection, which incorporates the right to be forgotten, has been recognized with prevalence in most of the cases. In all the judged cases and those which have to be treated in the future have to be taken in consideration also, the dangers that people face in digital environment, even why there are appreciated the importance of the right of information in a democratic society as a mechanisms for control, the role of the public authorities in realizing their duties and the activity of the media in performing their vital role as a social watchdog ${ }^{22}$. Hereto, for society based on the rule of law, it is important to also emphasize the necessity of establishing a fundamental value for every subject, who wants to remove his data and concretely, the necessity of legal certainty, which "requires that all law be sufficiently

18 The court has settled, the covert surveillance by public authorities, represents an arbitrary interference to the privacy, with regard to the unlawful method of the obtained information, See Judgment of European Court of Human Rights, case No. 31446/12 Ben Faiza v. France. The court has stressed "the lawfulness to obtain personal data, but not the content of calls, from telephone operators. See also Judgment of European Court of Human Rights, case No. 588/13 Benedik v. Slovenia. It is considered that the obtained information, by the police, associated with the dynamic IP address had not met the Convention standard of being "in accordance with the law".

19 Judgment of European Court of Human Rights, case No. 6188/07 Khelili v. Switzerland. See also Judgment of European Court of Human Rights case No. 24029/07 M. M v. United Kingdom, with court's focus on whether the data has been adequate and up to date. The court has emphasized "the necessity of sufficient safeguards in the system for retention and disclosure of criminal record data to ensure that data relating to the applicant's private life would not be disclosed in violation of her right for private life".

20 Judgment of European Court of Human Rights, case No. 60798/10 and 65599/10 M. L v. Germany. The decision has clarified the necessity of a "balancing test by considering the contribution by the right of expression through media articles and its archives" Also, the existence of "legitimate expectation for the public to be aware" through strengthened and updated information regarding discussions or facts on notable figures with effects on public order.

21 See Judgment of European Court of Human Rights, case No. 3877/14 Tamiz v. United Kingdom. Through this decision the court has accentuated the U.K.'s "real and substantial tort" test as an appropriate method for balancing of the freedom of expression and to possible violation of personal reputation from defamatory statements made in online blogs. The adequate balance was reasoned based on "the important role that information society service providers as Google Inc. perform in facilitating access to information and debate on a wide range of political, social and cultural topics" and the necessity of "a certain level of seriousness" to consider the anonymous comments made in online blog an attack on personal reputation.

22 We have borrowed this term from the Judgment of European Court of Human Rights, case No. 37374/05 Hungarian Civil Liberties Union v. Hungary. 
precise to allow the person - if need be, with appropriate advice - to foresee, to a degree that is reasonable in the circumstances, the consequences which a given action may entail"23.

About the balancing process of rights, we consider that the principle of proportionality, among the other applied principles, in every analysed case has directed the hull of the ship towards the tender balance between privacy and other values crucial to a person. This principle enables evaluation of the importance pertaining to context ${ }^{24}$; how it affects potential consequences to users ${ }^{25}$ and other specific circumstances and conditions of the case, without overlooking the fact that the regulation does not match with the "one size fits all approach"26.

While it is easy to note the application of the principles by the court in every adjudicated complaint, there are no legal principles that would dictate how the controllers decide to delist or retain the requested personal information. This creates ambiguity as to which of the goods or outcomes of the case the decision concerns, and, consequently, if the right to limit the access on personal information, in the future, has taken predominant precedence among other interests under the paragraph 3, Article 17 of the GDPR.

To ensure fair decisions of the controllers, we must integrate the relevance of the delisting interest into the mechanisms for transparency or institutionalization of the decision-making process. Transparency means that every controller applies the information deleting actions upon request and without delay, but at the same time it becomes necessary to periodically present the evidence of the handled requests. The evidence should be accessible to the national authorities of data protection, especially in case of data subjects' complaints.

\section{Conclusions}

Based on the increasing number and impact of the judgments of ECtHR on the right of erasure, it is clearly noted that a reciprocal infringement exists between this right and the freedom of expression and other protected rights. This consideration also supports our opinion presented in the current paper regarding the insufficient level of certainty to foresee the consequences entailed by the delisting request that are reasonable under the circumstances.

The lack of clarity about the scope and substance of the limitation and exceptions to be made in view of the right to be forgotten raises the question concerning the

23 Maxeiner J. R. Some realism about legal certainty in globalization of the rule of law. Available at: https://www.revolvy.com/page/Legal-certainty [last viewed May 3, 2019].

24 Ibid., 22.

25 Ibid., 22.

${ }^{26}$ Cellarius M. The right to informational self-determination: Keep it simple! Available at: https://www. europeanfiles.eu/digital/right-informational-self-determination-keep-simple [last viewed May 13, 2019]. 
establishment of mechanisms or authorities that are specialized in scrutinizing the delisting requests before the search engines administrate each of them. Otherwise, the appliance of the principle of proportionality will still remain in ambiguity and the dilemma in every of the reviewed case will suffer from the pressure of social needs or lack of transparency.

\section{BIBLIOGRAPHY}

1. Bernal P. A. A Right to Delete? European Journal of Law and Technology, Vol. 2, No. 2, 2011.

2. Reding V. Your data, your rights: Safeguarding your privacy in a connected world. The Review of the EU Data Protection Framework, Brussels, 16 March 2011.

\section{Normative acts}

3. Directive 95/46/EC of the European Parliament and of the Council of 24 October 1995 on the protection of individuals with regard to the processing of personal data and on the free movement of such data. Available at https://eur-lex.europa.eu/legal-content/en/ TXT/?uri=CELEX\%3A31995L0046 [last viewed May 6, 2019].

4. Regulation (EU) 2016/679 of the European Parliament and of the Council of 27 April 2016 on the protection of natural persons with regard to the processing of personal data and on the free movement of such data, and repealing Directive 95/46/EC (General Data Protection Regulation).

\section{Court practice}

5. Judgment of Court of Justice of the European Union case No. C-141/12 YS v. Minister voor Immigratie, Integratie en Asiel.

6. Judgment of Court of Justice of the European Union case No. C-372/12 Minister voor Immigratie, Integratie en Asiel $v M$ and $S$.

7. Judgment of European Court of Human Rights, case No. C-131/12, Google Spain SL, Google Inc. v. Agencia Espanola de Proteccion de Datos, Mario Costeja Gonzalez, p. 81.

8. Judgment of European Court of Human Rights, case No. 40660/08 and 60641/08 Von Hannover v. Germany.

9. Judgment of European Court of Human Rights, case No. 33846/07 Wegrzynowski and Smolczewski v. Poland, p. 5

10. Judgment of European Court of Human Rights, case No. 23373/03 Biriuk v. Lithuania.

11. Judgment of European Court of Human Rights, case No. 36919/02 Armonas v. Lithuania.

12. Judgment of European Court of Human Rights, case No. [2018] EWHC 799 (QB) NT1 and NT2 v. Google LLC.

13. Judgment of European Court of Human Rights, case No. 31446/12 Ben Faiza v. France.

14. Judgment of European Court of Human Rights, case No. 588/13 Benedik v. Slovenia.

15. Judgment of European Court of Human Rights, case No. 6188/07 Khelili v. Switzerland.

16. Judgment of European Court of Human Rights case No. 24029/07 M. M. v. United Kingdom.

17. Judgment of European Court of Human Rights, case No. 60798/10 and 65599/10 M. L. v. Germany.

18. Judgment of European Court of Human Rights case No. 3877/14 Tamiz v. United Kingdom. 
19. Judgment of European Court of Human Rights case No. 37374/05 Hungarian Civil Liberties Union v. Hungary.

\section{Internet sources}

20. Advocate General's Opinion in case No. C-390/18. Available at: https://curia.europa.eu/jcms/ upload/docs/application/pdf/2019-01/cp190001en.pdf [last viewed May 20, 2019].

21. Ambrose M. L, Ausloos J. The Right To Be Forgotten Across The Pond. Available at: https:// www.jstor.org/stable/pdf/10.5325/jinfopoli.3.2013.0001.pdf?refreqid=excelsior\%3Ae22d71 0ee435df378449357e74c68a0f [last viewed May 6, 2019].

22. Cellarius M. The right to informational self-determination: Keep it simple! Available at: https:// www.europeanfiles.eu/ digital/right-informational-self-determination-keep-simple [last viewed May 13, 2019].

23. Maxeiner J. R. Some realism about legal certainty in globalization of the rule of law. Available at: https://www.revolvy.com/ page/Legal-certainty [last viewed May 3, 2019].

24. Rouvroy A., Poullet Y. The Right to Informational Self-Determination and the Value of SelfDevelopment: Reassessing the Importance of Privacy for Democracy. Available at: https:// www.researchgate.net/publication/225248944_The_Right_to_Informational_Self-Determination_and_the_Value_of_Self-Development_Reassessing_the_Importance_of_Privacy_for_ Democracy [last viewed May 2, 2019].

25. Schwartz P. The EU-U.S. Privacy Collision: A Turn to Institutions and Procedures. Available at: https://scholarship.law.berkeley.edu/cgi/viewcontent.cgi?article=2906\&context=facpubs [last viewed March 10, 2019].

26. Wechsler S. The Right to Remember: The European Convention on Human Rights and the Right to Be Forgotten. Available at: http://jlsp.law.columbia.edu/wp-content/uploads/ sites/8/2017/03/49-Wechsler.pdf [last viewed May 5, 2019]. 